\title{
THE FOOD OF ROACH, RUTILUS RUTILUS (ACTINOPTERYGII: CYPRINIFORMES: CYPRINIDAE), IN A BIOMANIPULATED WATER SUPPLY RESERVOIR
}

\author{
Tomáš ZAPLETAL ${ }^{1 *}$, Jan MAREŠ ${ }^{1}$, Pavel JURAJDA ${ }^{2}$, and Lucie VŠETIČKOVÁ ${ }^{2}$ \\ ${ }^{1}$ Department of Zoology, Fisheries, Hydrobiology and Apiculture, Faculty of Agronomy, \\ Mendel University, Brno, Czech Republic \\ ${ }^{2}$ Institute of Vertebrate Biology Academy of Sciences Czech Republic, Brno, Czech Republic
}

\begin{abstract}
Zapletal T., Mareš J., Jurajda P., Všetičková L. 2014. The food of roach, Rutilus rutilus (Actinopterygii: Cypriniformes: Cyprinidae), in a biomanipulated water supply reservoir. Acta Ichthyol. Piscat. 44 (1): $15-22$.
\end{abstract}

Background. Roach, Rutilus rutilus (Linnaeus, 1758), is an omnivorous fish species that is able to utilise a range of food resources. Both juvenile and older roach can negatively affect zooplankton abundance in freshwater bodies of water; hence populations are often reduced (biomanipulated) in order to increase zooplankton populations. The aim of this study was to assess the roach diet after large-scale removal of cyprinids (bream, roach) from a reservoir. The study was done to clarify the roach diet after three years of intensive reduction of cyprinid fish and also to find out how the roach feeding behaviour impacts the quantity of filtering zooplankton. As such, this study may help to explain more general relations within the aquatic food web and specify the roach diet during the vegetative season (from spring to autumn).

Materials and methods. This study was undertaken at the Hamry water supply reservoir in the Czech Republic. Samples of macrozoobenthos, periphyton, and zooplankton were collected as representative food resources. Fish were caught using a 100-m littoral beach seine during the April to October growing season in 2011. Supplementary fish were caught using a pelagic Nordic gillnet in August and September 2012 and a 15-m beach seine in June and August 2012. Gut contents were preserved in 4\% formaldehyde for later laboratory analysis (frequency of occurrence, index of preponderance, index of gut fullness).

Results. 'Detritus' was the major component found in roach guts, with no difference observed in age category or locality (littoral vs. open water areas). Significant differences were observed, however, between younger $(0+$ and $1+, 36-92 \mathrm{~mm})$ and older $(>3$ years, $>92 \mathrm{~mm})$ fish. The $0+$ and $1+$ age groups also fed on zooplankton $(P<0.008)$, accompanied by Chironomidae $(1+)$, while diet of older roach $(3-4+; 6-8+)$ included macrophytes and periphyton, together with Cladocera (fish from open water; $P<0.008$ ).

Conclusion. The results demonstrate that detritus was the main 'dietary' component of roach during the growing season, with macrophytes and periphyton as complementary dietary items. Zooplankton was an important dietary component of mainly younger roach age classes. Roach appear to be an important component in ichthyo-eutrophication of the Hamry Reservoir, mainly through transfer of phosphorous from plants to water.

Keywords: diet analysis, gut, biomanipulation, age groups

\section{INTRODUCTION}

Roach, Rutilus rutilus (Linnaeus, 1758); bream, Abramis brama (Linnaeus, 1758); and European perch, Perca fluviatilis Linnaeus, 1758 typically dominate fish stocks in water supply reservoirs (drinking water reservoir) of the Czech Republic (Pivnička 1992). Roach are feeding generalists, usually utilising the most available food resource (Hellawell 1972, Prejs and Jackowska 1978, Prejs 1984, Horppila and Nurminen 2009). Such dietary plasticity allows it to find food in habitats offering less than ideal conditions for other species, whose feeding demands may be greater (Baruš and Oliva 1995).

Planktonic crustacean such as Cladocera and Copepoda tend to dominate in the food of younger age classes; Tarvainen et al. (2002), for example, found $0+$ roach $(71-90 \mathrm{~mm})$ to be exclusively zooplanktivorous (Bosmina, Chydorus), while Hammer (1985) observed the same cladoceran species dominating roach fry diet in Lake Lankau (Germany). Similarly, Vašek et al. (2006) as well as Peterka and Matěna (2009) have both described

* Correspondence: Dr. Tomáš Zapletal, Ústav zoologie, rybářství, hydrobiologie a včelařství, Agronomická fakulta, Mendelova univerzita v Brně, Zemědělská 1/1665, 61300 Brno; Czech Republic. Phone: +420605 402 077, e-mail: (TZ) zapletal.tomas@email.cz; (JM) mares@mendelu.cz; (PJ) jurajda@brno.cas.cz; (LV) lucka.kocanda@seznam.cz. 
zooplankton as the main food of $0+$ roach in Czech reservoirs. The proportion of zooplankton in roach diet changes, however, according to ontogenetic stage, with the proportion of macrophytes and detritus increasing as the fish gets older (Matěna 1995, 1998).

In deep valley reservoirs lacking shallow vegetated shorelines, zooplankton also represents a major dietary element in older roach age classes (Kubečka et al. 1998, Vašek and Kubečka 2004). Linfield (1980), when studying roach diet in lakes of northern Britain, found that diet changed with fish length, with roach $<100 \mathrm{~mm}$ consuming mostly Cladocera $(23 \%-29 \%)$, phytoplankton $(7 \%-23 \%)$, Diptera $(5 \%-17 \%)$, and macrophytes $(6 \%-13 \%)$. The quantity of Cladocera and macrophytes decreased to $9 \%-13 \%$ and $10 \%-12 \%$, respectively, and the quantity of Diptera, algae, and Trichoptera increased up to $8 \%-28 \%, 6 \%-10 \%$, and $2 \%-10 \%$, respectively, in roach longer than $100 \mathrm{~mm}$.

In analysing gut contents of adult roach (120-240 $\mathrm{mm}$ ) from the Włocławek Reservoir in Poland, Szczyglińska (1987) found that roach ate mainly plants and aquatic macroinvertebrates (mostly Pisidium sp. and Viviparus viviparus), with 'detritus' and sand also occurring in each alimentary tract. Brabrand (1985) noted that lower macroinvertebrate availability resulted in greater proportion of macrophytes in roach diet in a mesotrophic lake in north-eastern Norway. Similarly, during a period of low zooplankton abundance in a eutrophic lake in Finland, larger roach were observed to concentrate on plants and detritus as food items (Horppila and Peltonen 1997). Martyniak et al. (1991), who analysed the diet of $145-420 \mathrm{~mm}$ roach in the Pierzchały Reservoir in Poland, found that the most frequently and regularly eaten items were dreissenids $(50 \%)$, larvae of Chironomidae and macrophyte material.

In a number of reservoirs, large numbers of cyprinids (e.g., bream, roach) have been removed in an attempt to affect the reservoir's food cascade, a process commonly termed biomanipulation. Excessive consumption of zooplankton by planktivorous fish can lead to algal blooms, which can seriously affect drinking water quality (Dokulil and Teubner 2000, Walker et al. 2007). Removal of large numbers of roach and bream (ca. $100 \mathrm{~kg}$ per hectare), along with large-scale stocking of predatory fish is expected to result in an increase in zooplankton density and an improvement in water quality (Prejs et al. 1994).

Between 2009 and 2011, 10438 adult cyprinid fish weighing $3774 \mathrm{~kg}$ were removed from the Hamry Reservoir, including 8685 bream $(>200 \mathrm{~mm})$ and 1753 roach $(>160 \mathrm{~mm})$. The fish were removed from the reservoir early in the spawning season each year between April and May, the fish lengths taken corresponding to fish of four years and older (i.e., capable of spawning). Simultaneously, each May and June (2009-2011), 285000 bream larvae/juveniles and 395000 roach larvae/juveniles were also removed. Alongside removal of cyprinids, zooplankton quantities were also determined. Overall, the species composition of cladoceran zooplankton showed no change.
The aim of this study was to assess the diet of roach following the large-scale removal of cyprinids (bream, roach) from the reservoir. We hypothesise that the largescale removal of roach from the reservoir will help improve zooplankton development. Such a result would add support to fish removal from water supply reservoirs with the aim of improving long-term water quality and lowering treatment costs.

\section{MATERIAL AND METHODS}

Study site. This study was carried out at the Hamry water supply reservoir $\left(49^{\circ} 43^{\prime} 52^{\prime \prime} \mathrm{N}, 15^{\circ} 55^{\prime} 1^{\prime \prime} \mathrm{E}\right)$, near the town of Hlinsko in the Bohemian-Moravian highlands of the Czech Republic. Built between 1907 and 1912, the reservoir is fed by the River Chrudimka and was originally intended as a single-purpose structure for protecting Hlinsko and its surroundings against flooding. The dam is $17.4 \mathrm{~m}$ high with its crest at an elevation of $602.86 \mathrm{~m}$. The reservoir is 42.3 ha in size and has a catchment area of $56.8 \mathrm{~km}^{2}$; average depth is $2 \mathrm{~m}$, with a maximum depth by the dam of $7.5 \mathrm{~m}$. The reservoir presently serves as a drinking water source for Hlinsko and its surroundings. About half of the shoreline is associated with bankside meadows with a gentle slope and shore macrophytes that are flooded during higher water levels. The reminder of the shoreline has steep banks covered by a coniferous forest and its littoral zone featuring limited macrophyte vegetation. The inlet area is shallow with soft sediment and a thick layer of detritus from decaying meadow grass beds. Methods. Littoral macrozoobenthos and periphyton were monitored monthly from April to August and in October of 2011 and 2012. At the same time, zooplankton samples were taken from three points of different depth (Fig. 1).

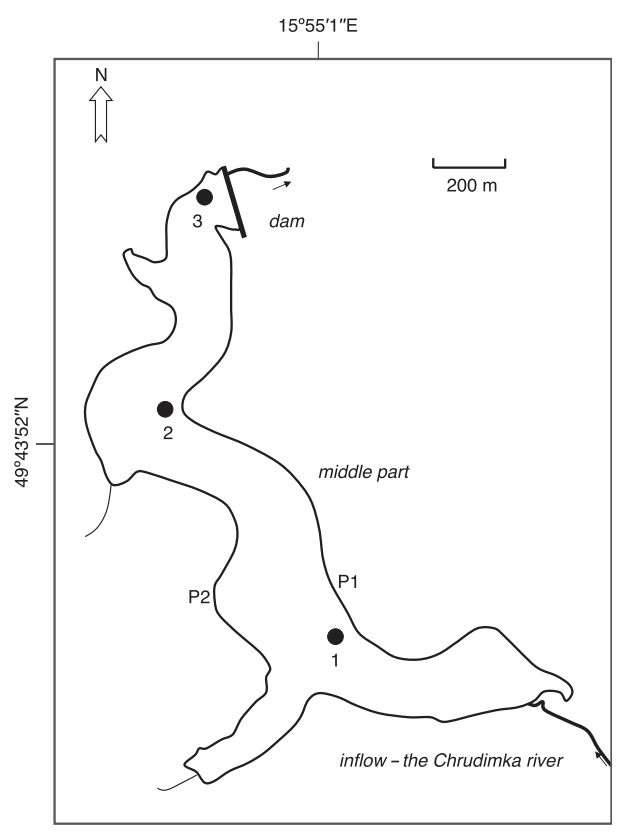

Fig. 1. Map of the Hamry water supply reservoir with sampling sites indicated (Sites 1, 2 and 3 indicate zooplankton sampling sites; P1 and P2 indicate macrozoobenthos and periphyton sampling sites) 
Zooplankton samples from site 1 (depth $1.5 \mathrm{~m}$ ) were taken using a standard $20 \mathrm{~cm}$ diameter zooplankton net towed horizontally for $6 \mathrm{~m}$. Zooplankton samples from sites 2 (depth $4 \mathrm{~m}$ ) and 3 (depth $7 \mathrm{~m}$ ) were taken with the same equipment, but the net was pulled out vertically from depths of 4 and $6 \mathrm{~m}$, respectively (see Přikryl 2006.

Submerged littoral vegetation was sampled manually at two littoral sites in order to examine overgrowing periphyton. Periphyton is expressed as percentage frequency between taxa.

Macrozoobenthos samples were taken simultaneously using a modified version of the PERLA method (Kokeš and Němejcová 2006), i.e., multi-habitat sampling with all habitats sampled proportionally. Samples were collected using a benthos net and kick-sampling for 3-min intervals. All zooplankton and macrozoobenthos samples were preserved in $4 \%$ formaldehyde. Macrozoobenthos samples were processed by removal of all organisms present in the sample or, if the sample was large, from a representative part (minimum 25\%). Organisms were determined to the lowest possible taxonomic level and number of individuals per sample, and their relative abundance was calculated by dividing the number of individuals $n$ in the sample $(\times 100)$ by the number of all individuals in the sample.

Depending on the volume of zooplankton, a subsample of 4,5 , or $6 \mathrm{~mL}$ was taken from a known volume of each plankton sample and placed into a counting chamber. Zooplankton organisms were identified in the laboratory of Povodí Labe, s.e., the authority responsible for managing the reservoir. Organisms present were determined, counted, and expressed as number of individuals per $\mathrm{m}^{3}$. The organisms were then separated by size using a sieve, i.e., those $100-700 \mathrm{~mm}$ and those $>700$, for future analysis.

Fish were sampled using a $100-\mathrm{m}$ beach seine (maximum depth $4 \mathrm{~m}$, mesh size $20 \mathrm{~mm}$ ) along the shallow banks of the reservoir during the day in April, June, July, and October of 2011. During 2009, some fish were also sampled by electrofishing. Based on results from 2011, an additional sampling (September 2012) was completed using Nordic gillnets to collect fish from open water (overnight exposure). Only live fish were used for further analysis. Younger fish were sampled using a fry beach seine (15 m long, $2 \mathrm{~m}$ depth, $4 \mathrm{~mm}$ mesh size) in June and August 2012. On each occasion, ca. 20 individuals from the four dominant age (size) categories $(0+$ of $36-52 \mathrm{~mm}$, $1+$ of 55-92 mm, 3-4+ of 73-163 mm, and 6-8+ of 163-266 mm standard length; SL) were taken for diet analysis. The length frequency distribution of all roach sampled over 2011 and 2012 is displayed in Fig. 2.

Immediately after capture, fish were weighed (to the nearest $0.1 \mathrm{~g}$ ), measured (SL; to the nearest $1 \mathrm{~mm}$ ), then dissected and the gut contents separated. The gut contents were weighed (to the nearest $0.1 \mathrm{~g}$ ) and preserved in $4 \%$ formaldehyde for later laboratory analysis.

A modification of the gravimetric method used by Hyslop (1980) was used to analyse food content in the laboratory. Mucus and mineral particles were separated from the sample and not included in further food analysis. The bulk of the sample, which consisted of macrophytes and detritus, was separated from determinable taxa under a binocular microscope; taxa were then examined under a magnification ranging from $40 \times$ to $450 \times$. The proportion of total food intake $\left(W_{T}\right)[\%]$ represented by each category was evaluated using the indirect method of Hyslop (1980), using the following formula:

$$
W_{T}=100\left(W_{i} \cdot \Sigma W_{i}^{-1}\right)
$$

where: $W_{i}$ is the weight of an individual food component $i$ and $\Sigma W_{i}$ is the weight of all food components combined.

Frequency of occurrence (FO) [\%] of food items was calculated according to Pivnička (1981) using the formula:

$$
\mathrm{FO}=100\left(n \cdot \Sigma n^{-1}\right)
$$

where: $n$ is the number of guts containing a particular dietary component and $\Sigma n_{i}$ is the number of all guts.

These two criteria are combined in order to express an index of preponderance (IP) using the following formula:

$$
\mathrm{IP}=100\left(W_{i} \cdot \mathrm{FO}_{i}\right) \cdot \Sigma\left(W_{i} \cdot \mathrm{FO}_{i}\right)^{-1}
$$

where: $W_{i}$ is the weight percentage of a particular food component $i$ and $\mathrm{FO}_{i}$ is the frequency of occurrence of that food component. This provides a relevant measurable basis for sorting particular components and presents results that are a combination of frequency of occurrence and weight contribution of particular components (Natarajan and Jhingran 1961).

Food bulk weight was assessed to the nearest $\mathrm{mg}$ and presented as the index of gut fullness (IF) $[\%$ ooo $]$ using the formula:

$$
\text { IF }=10^{4} w \cdot W^{-1}
$$

where: $w=$ food weight, $W=$ fish weight.

The percentage of each food item was compared separately using Mann-Whitney tests with Bonferroni correction of significance level to decrease the probability of committing a type I error in multiple testing (Sokal and Rohlf 1995). Bonferroni correction was applied in order to control familywise error rate in cases of multiple testing. For each food item, 6 cross-comparisons $(0+$ vs. $1+$, $0+$ vs. $3+-4+, 0+$ vs. $6+-8+, 1+$ vs. $3+-4+, 1+$ vs. $6+-8+$, $3+-4+$ vs. $6+-8+)$ were conducted, thus correcting the significance level $\alpha$ from its original value of 0.05 to $0.05 \times 6^{-1}=0.008$.

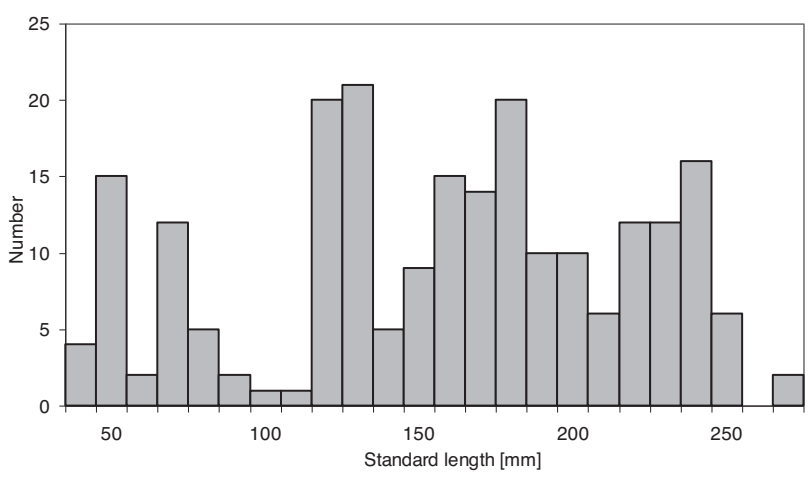

Fig. 2. Length-frequency distribution of roach, Rutilus rutilus, sampled from the Hamry Reservoir, Czech Republic, in 2011 and 2012 
We declare that this study has been carried out in accordance with the valid legislation of the Czech Republic, particularly under laws No. 114/1992 Coll. No. 246/1992 Coll. and Instruction No. 554/77-34. No organism sampled in this study represented a species protected in the Czech Republic.

\section{RESULTS}

Food resources. From April through August, chironomid larvae were the dominant macrozoobenthic organisms, while Ephemeroptera and Mollusca dominated in October (Fig. 3). Bacillariophyceae were dominant in the periphyton assemblage throughout the year (Fig. 4). Cladocera $>$ $700 \mu \mathrm{m}$ were dominant in total volume of zooplankton over 2011-2012 (Fig. 5).

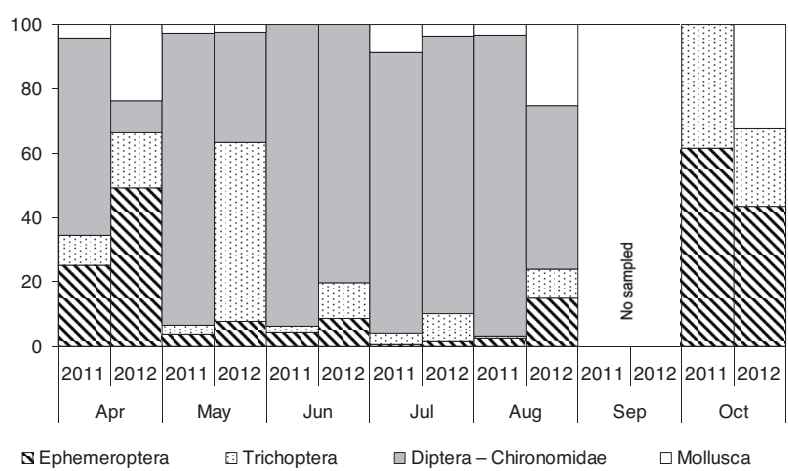

Fig. 3. Monthly macrozoobenthos composition at the Hamry Reservoir, Czech Republic, in 2011 and 2012

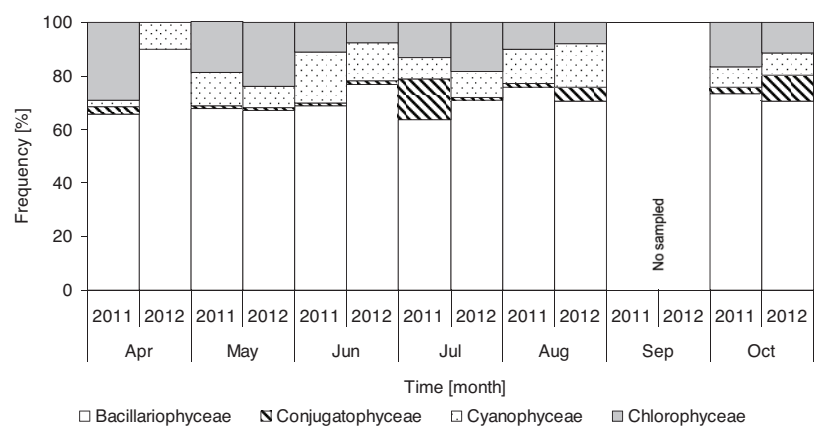

Fig. 4. Monthly periphyton composition at the Hamry Reservoir, Czech Republic, in 2011 and 2012

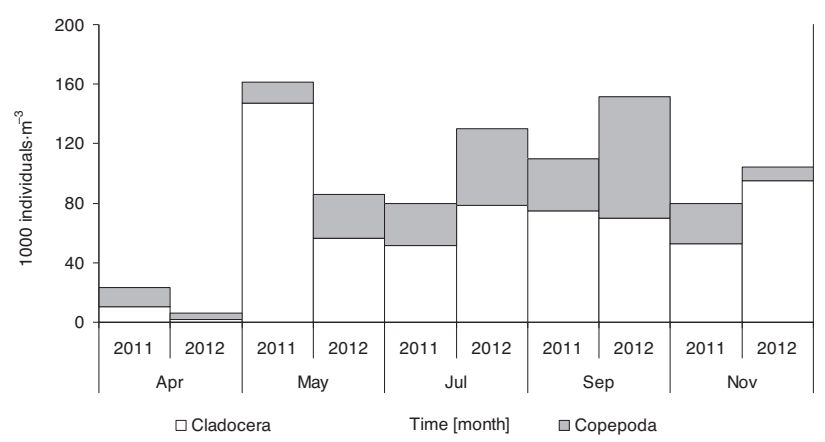

Fig. 5. Monthly zooplankton composition at the Hamry Reservoir, Czech Republic, in 2011 and 2012
Food of roach. The diet of $0+$ roach consisted mainly of detritus (IP 63.8) and Cladocera (IP 33.8), with Copepoda (IP 2.4) being much less consumed (Table 1). Macrophytes remains were not recorded in the youngest age group. Roach fry consumed significantly more Cladocera and Copepoda than roach $>6-8+(P<0.008)$. No significant difference in detritus consumption was observed between $0+$ and older groups $(P>0.008)$.

Detritus was dominant in 1+ roach diet (IP 82.6, Table 1), followed by Cladocera (IP 8.9) and Chironomidae (IP 7.0). Macrophytes (IP 1.0) and Copepoda (IP 0.5) were less important. 1+ roach consumed less zooplankton but more Chironomidae than $0+$ roach (Fig. 6), and significantly more Cladocera and Chironomidae than older roach $(P<0.008)$.

The dominant food item of 3-4+ roach was detritus (IP 74.2 \pm 5.0 ), with macrophytes (IP $16.1 \pm 5.5$ ) and periphyton (IP $7.5 \pm 1.3$ ) of secondary importance, both varying according to season. Cladocera, Chironomidae, Mollusca, Trichoptera, Copepoda, and Ephemeroptera were all marginal dietary components (Table 2). The average index of fullness in this group was $177.5 \%$ ooo, with minimum values in April and maximum in June (Fig. 7).

Detritus was the main food item for 6-8+ roach caught in the littoral zone (IP $55.8 \pm 19.5$ ) throughout the monitored season, except for June when periphyton was dominant (IP 62.5). Macrophytes (IP $19.7 \pm 15.4$ ) were also frequently consumed, with highest consumption in April. Other items were consumed only occasionally (Table 2, Fig. 6). Average index of fullness for littoral zone 6-8+ roach was $197.3 \%$ ooo. Roach sampled in open water consumed primarily periphyton (IP 46.9), detritus (IP 27.4), and Cladocera (IP 15.8), with macrophytes (IP 8.7) also

Table 1

Index of preponderance of young $(1+; 0+)$ and adult (6-8+) roach, Rutilus rutilus, in the Hamry Reservoir, Czech Republic, in 2012

\begin{tabular}{|c|c|c|c|c|}
\hline & \multicolumn{3}{|c|}{ Date and age group } \\
\hline & & $\begin{array}{c}11 \text { Jun } \\
(1+)\end{array}$ & $\begin{array}{c}23 \text { Aug } \\
(0+)\end{array}$ & $\begin{array}{c}23 \text { Aug-20 Sep } \\
(6-8+)\end{array}$ \\
\hline \multirow{6}{*}{ 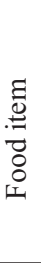 } & Cladocera & 8.9 & 33.8 & 15.8 \\
\hline & Copepoda & 0.5 & 2.4 & 1.2 \\
\hline & Chironomidae & 7.0 & 0 & 0.7 \\
\hline & Macrophytes & 1.0 & 0 & 8.7 \\
\hline & Periphyton & 0 & 0 & 46.9 \\
\hline & Detritus & 82.6 & 63.8 & 27.4 \\
\hline \multirow{6}{*}{ 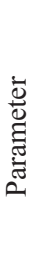 } & $n$ & 20 & 20 & 20 \\
\hline & $n_{0}$ & 0 & 0 & 0 \\
\hline & $\mathrm{TL}[\mathrm{mm}]$ & $87.6 \pm 9.6$ & $54.8 \pm 4.6$ & $265.4 \pm 34.6$ \\
\hline & $\mathrm{SL}[\mathrm{mm}]$ & $70.1 \pm 8.4$ & $44.1 \pm 4.0$ & $219.1 \pm 29.9$ \\
\hline & $\mathrm{SL}$ range $[\mathrm{mm}]$ & $55.0-92.0$ & $36.0-52.0$ & $150.0-266.0$ \\
\hline & $W[\mathrm{~g}]$ & $6.8 \pm 2.3$ & $1.7 \pm 0.4$ & $234.1 \pm 84.2$ \\
\hline
\end{tabular}

Length and weight values are mean \pm standard deviation; $n=$ number of fish, $n_{0}=$ number of fish without food, $\mathrm{TL}=$ total length of fish, $\mathrm{SL}=$ standard length, $W=$ fish weight. 
being taken. While roach in open water consumed more Cladocera than littoral roach, food from the littoral zone still dominated in the diet, indicating that these fish moved in-shore to feed over the dial period.

Changes in assemblage structure and quantity following the fish removal clearly indicate a decrease in predatory pressure on filtering zooplankton (Fig. 8).

\section{DISCUSSION}

Detritus was the dominant food item of roach in Hamry Reservoir, regardless of site, age, or date of capture supplemented with macrophytes, periphyton, and zooplankton. Zooplankton never formed a substantial part of the diet. The results indicate that roach periodically move between the littoral and open water zones, thereby utilising food over the whole reservoir. Studies in shallow lakes in Poland have also found that detritus, macrophytes, and periphyton formed significant components of roach diet (Klimczyk-Janikowska 1978, TarkowskaKukuryk 2008).

In the Mušovská Reservoir (mean depth $1.5 \mathrm{~m}$ ), a shallow lake with a developed littoral zone in the Czech Republic, Adámek et al. (1985) observed that roach consumed mainly detritus and zooplankton at offshore sites, and detritus and periphyton at inshore sites, indicating that roach used all the food items accessible in its immediate vicinity. While it might be expected that results would be similar in shallow reservoirs, in a relatively shallow eutrophic lake in Denmark (mean depth $3.1 \mathrm{~m}$ ), roach fed mainly on zooplankton (Michelsen et al. 1994). Zoobenthos were of minor importance and detritus appeared only in periods of low animal-food availability.
In this case, it may be that roach displayed lower feeding efficiency on prey living in the sediment comparing to other species, e.g., sub-adult perch.

The most significant changes in roach food composition are found in steep-sided canyon-shaped valley reservoirs,

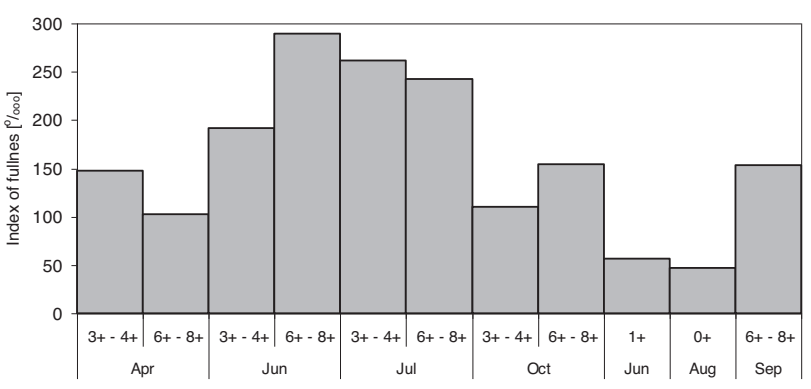

Fig. 6. Seasonal diet composition for roach at the Hamry Reservoir, Czech Republic, in 2011 and 2012

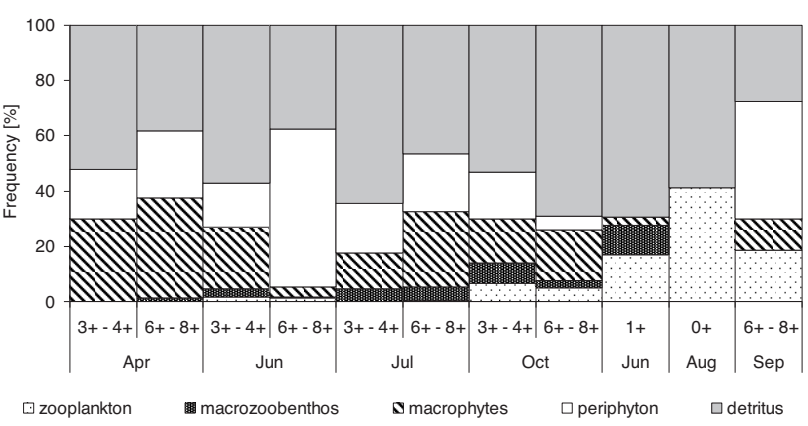

Fig. 7. Index of fullness dynamics for a range of age classes of roach, Rutilus rutilus, at the Hamry Reservoir, Czech Republic, in 2011 and 2012

Table 2

Index of preponderance for roach, Rutilus rutilus, in the Hamry Reservoir, Czech Republic, in 2011 Date and age group

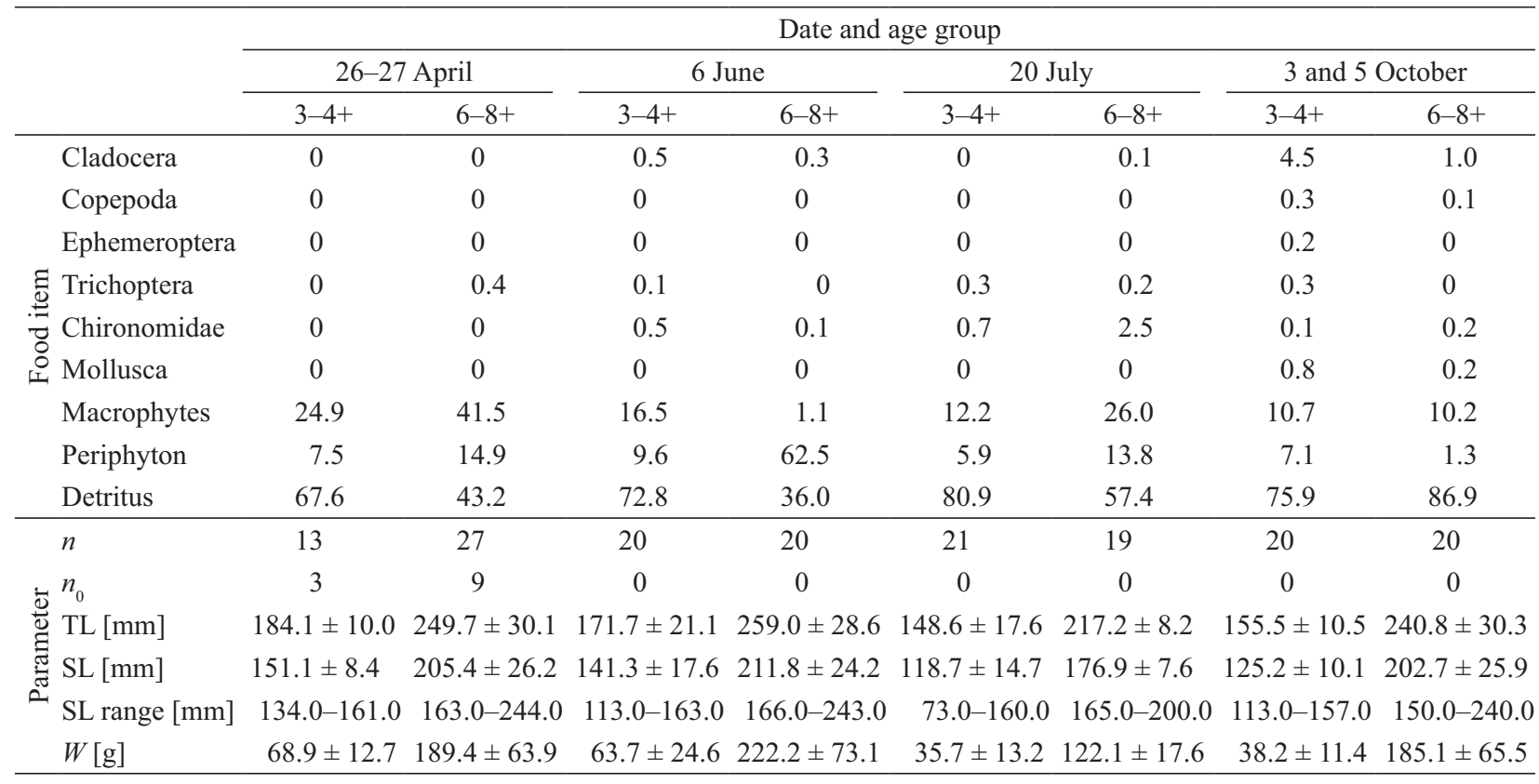

Length and weight values are mean \pm standard deviation; $n=$ number of fish, $n_{0}=$ number of fish without food, TL $=$ total length of fish, $\mathrm{SL}=$ standard length, $W=$ fish weight. 
where macrophytes are generally absent. Hammer (1985), Ponton and Gerdeaux (1988), Giles et al. (1990), and Peterka and Matěna (2009) all found roach to specialise in feeding on crustacean zooplankton at such sites only Richeux et al. (1992) found, by contrast, in the deep lake of Pareloup (Massif Central, France) that smaller roach $(10-21 \mathrm{~cm})$ had a diet chiefly of detritus and zooplankton, whilst oldest individuals were detritivores. While roach typically select zooplankton in deep reservoirs, its ability to feed on detritus may also provide it with an energetic advantage, increasing the carrying capacity for this species in lakes where detritus occurs and is accessible. This may also be important in habitats where feeding competition occurs between roach and perch due to juvenile perch favouring macrozoobenthos (Okun and Mehner 2005). Adámek et al. (1987) sampled fish at two sites (middle and upper tributary) in a deep reservoir (maximum depth $85.5 \mathrm{~m}$ ), and found that roach fed chiefly on detritus (49\%) and zooplankton (40\%) in the canyon-shaped middle section, and macrophytes (48\%) together with detritus $(36 \%)$ in the shallow upper section with a rich littoral zone. The high proportion of detritus indicated an offshore-inshore foraging movement, as also indicated in this study.

The majority of the above-mentioned publications did not distinguish age categories in the fish studied. Our results, however, indicate that there are age differences, with one-year-old fish consuming mainly detritus and zooplankton and older fish showing a significant preference for detritus, macrophytes, and periphyton. Age differences have also been observed by Horppila (1994), who found that the importance of zooplankton decreased and that of benthos and plants increased, with increasing roach size. Similarly, Volta and Jepsen (2008) observed a clear age difference when comparing diet of in shallow and deep reservoirs, with young roach consuming mainly algae and older specimens consuming mainly zooplankton, detritus and macrozoobenthos.

While a number of authors have considered adult roach to be molluscivorous (Prejs 1976, Szczyglińska 1987, Specziár et al. 1997), we observed no preference for Mollusca, even in larger roach $(>163 \mathrm{~mm})$. Note, however, that representation of Mollusca in the macrozoobenthos assemblage did increase slightly in autumn.

Prior to the large-scale removal of cyprinids documented in this study, only Šampalík (unpublished*) had studied roach feeding activity in the Hamry Reservoir. His study, however, took place during the spawning period (April-June) in 2009 and 2010. He found that macrophytes were the dominant food component $(50 \%-70 \%)$ of roach diet. In comparison with our results, therefore, there has been no obvious change in overall diet. Inshore roach samples, collected using the same method as Šampalík (unpublished), indicate that detritus and periphyton had slightly increased in roach diet in 2011, and macrophytes slightly decreased. In comparison, a dietary shift was observed at a lake in Finland following biomanipulation, when biomass of roach and bream was reduced to $33 \%$

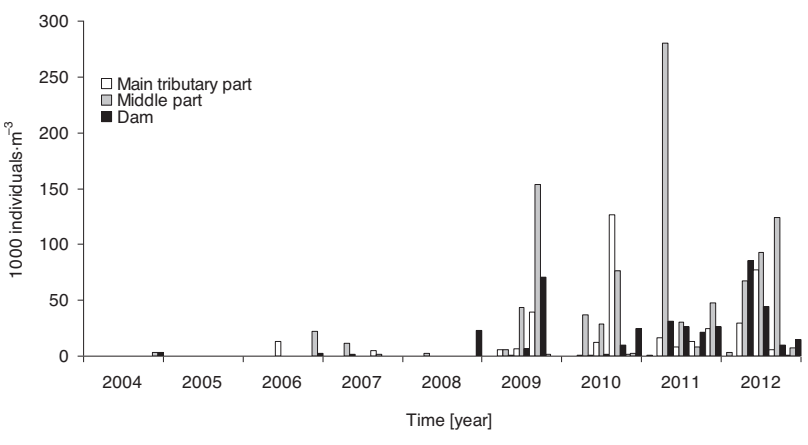

Fig. 8. Zooplankton abundance at the Hamry Reservoir, Czech Republic, during the five years before fish removal (2004-2008; data supplied by Povodí Labe) and from 2009 to 2012

and $10 \%$, respectively. Roach of almost all size classes started to forage on macrozoobenthos. In this case, however, the lake in question had no submerged littoral zone available as an alternative food source (Persson and Hannson 1999).

Roach are able to utilise a wide range of available food resources due to their feeding plasticity. In deep canyon reservoirs with an absence of macrophytes, therefore, adult roach tend to consume cladocerans zooplankton; while in shallow reservoirs with flooded macrophytes, periphyton (e.g., diatoms) is used as easily accessible food source for both sub-adult and adult roach.

Younger roach age classes (i.e., $0+$ and $1+$ ) can play a negative role in water quality management when planktonic filtrators form the major part of food. On the other hand, older fish can also contribute to eutrophication when their feeding is primarily focused on detritus and macrophytes, through the transfer of phosphorus in plants back into the water. In this study, despite the dominant food item being detritus and Cladocera averaging only $21.35 \%(0+$ and $1+$ category) and $2.47 \%(3-4+$ and $6-8+$ category), this volume of Cladocera in roach diet proved important for the filtering ability of the whole community. Large-scale removals of cyprinid fish, therefore, can contribute significantly to the development of filtering zooplankton populations.

\section{ACKNOWLEDGEMENTS}

This study was supported through research project ECIP P505/12/G112 of the "European Centre of Ichthyoparasitology". The authors would like to thank Dr. Jan Špaček and Dr. Václav Koza, for their invaluable help in determining aquatic invertebrates and periphyton, and their colleagues at the Academy of Sciences-Institute of Vertebrate Biology, especially Dr. Michal Janáč for his help in statistical evaluation and Dr. Kevin Roche for English correction. Last but not least we thank the management of Povodí Labe s.e. for permission to sample at the reservoir, for providing zooplankton data and for valuable financial support.

\footnotetext{
* Šampalík J. 2010. Př́jem potravy ploticí obecnou (Rutilus rutilus) v období tření. [Food intake of roach (Rutilus rutilus) during the spawning period.] MSc Thesis. Faculty of Fisheries and Protection of Waters, University of South Bohemia, České Budějovice, Czech Republic. [In Czech with English summary.]
} 


\section{REFERENCES}

Adámek Z., Jirásek J., Pravda D., Sukop I., Heteša J., Provázek R., Škrabánek A. 1985. ["The food biology and biological value of roach (Rutilus rutilus L.) in the Mušovská Reservoir”.] Živočišná Výroba 30 (10): 901-910. [In Czech with English abstract.]

Adámek Z., Jirásek J., Sukop I. 1987. ["The food biology of the economically important fishes in the Dalešice Reservoir".] Živočišná Výroba 32 (10): 909-920. [In Czech with English abstract.]

Baruš V., Oliva O. (eds.) 1995. Mihulovci Petromyzontes a ryby Osteichthyes (2). [Cyclostomes Petromyzontes and fishes Osteichthyes (2).] Academia, Praha, Czech Republic. [In Czech.]

Brabrand Å. 1985. Food of roach (Rutilus rutilus) and ide (Leusiscus [sic] idus): significance of diet shift for interspecific competition in omnivorous fishes. Oecologia 66 (4): 461-467. DOI: 10.1007/BF00379334

Dokulil M.T., Teubner K. 2000. Cyanobacterial dominance in lakes. Hydrobiologia 438 (1-3): 1-12. DOI: 10.1023/A: 1004155810302

Giles N., Street M., Wright R.M. 1990. Diet composition and prey preference of tench, Tinca tinca (L.), common bream, Abramis brama (L.), perch, Perca fluviatilis L. and roach, Rutilus rutilus (L.), in two contrasting gravel pit lakes: potential trophic overlap with wildfowl. Journal of Fish Biology 37 (6): 945-957. DOI: 10.1111/j.1095-8649.1990. tb03598.x

Hammer C. 1985. Feeding behaviour of roach (Rutilus rutilus) larva and the fry of perch (Perca fluviatilis) in Lake Lankau. Archiv für Hydrobiologie 103 (1): 61-74.

Hellawell J.M. 1972. The growth, reproduction and food of the roach Rutilus rutilus (L.) of the River Lugg, Herefordshire. Journal of Fish Biology 4 (4): 469-486. DOI: 10. 1111/j.1095-8649.1972.tb05696.x

Horppila J. 1994. The diet and growth of roach (Rutilus rutilus (L.)) in Lake Vesijärvi and possible changes in the course of biomanipulation. Hydrobiologia 294 (1): 35-41. DOI: 10.1007/BF00017623

Horppila J., Nurminen L. 2009. Food niche segregation between two herbivorous cyprinid species in a turbid lake. Journal of Fish Biology 75 (6): 1230-1243. DOI: 10.1111/j.1095-8649.2009.02359.x

Horppila J., Peltonen H. 1997. A bioenergetic approach to food consumption of roach (Rutilus rutilus (L.) in a eutrophic lake. Archiv für Hydrobiologie 139 (2): 207-222.

Hyslop E.J. 1980. Stomach contents analysis - a review of methods and their application. Journal of Fish Biology 17 (4): 411-429. DOI: 10.1111/j.1095-8649.1980.tb02775.x

Klimczyk-Janikowska M. 1978. Influence of warmed water on the growth and feeding of the roach Rutilus rutilus L. Acta Hydrobiologica 20 (2): 175-185.

Kokeš J., Němejcová D. 2006. Metodika odběru a zpracování vzorků makrozoobentosu tekoucích vod metodou PERLA. [Methodology for macrozoobenthos sampling in running waters and sample processing using the Perla method.] VÚV TGM Prague, Czech Republic. [In Czech.]
Kubečka J., Sed'a J., Matěna J. 1998. Fish-zooplankton interactions during spring in a deep reservoir. International Review of Hydrobiology 83 (Special Issue): 431-442.

Linfield R.S.J. 1980. Ecological changes in a lake fishery and their effects on a stunted roach Rutilus rutilus population. Journal of Fish Biology 16 (2): 123-144. DOI: 10.1111/j.1095-8649.1980.tb03692.x

Martyniak A., Gitler K., Adámek Z. 1991. Food biology of roach (Rutilus-rutilus) in the Pierzchaly Reservoir (Poland). Folia Zoologica 40 (4): 377-384.

Matěna J. 1995. The role of ecotones as feeding grounds for fish fry in a Bohemian water supply reservoir. Hydrobiologia 303 (1-3): 31-38. DOI: 10.1007/BF00034041

Matěna J. 1998. Diel spectra and competition between juvenile fish in a pelagic zone of a deep stratified reservoir during the first year of life. International Review of Hydrobiology $\mathbf{8 3}$ (Special Issue): 577-583.

Michelsen K., Pedersen J., Christoffersen K., Jensen F. 1994. Ecological consequences of food partitioning for the fish population structure in a eutrophic lake. Hydrobiologia 291 (1): 35-45. DOI: 10.1007/BF00024237

Natarajan A.V., Jhingran A.G. 1961. Index of preponderance - a method of grading the food elements in the stomach analysis of fishes. Indian Journal of Fisheries 8: 54-59.

Okun N., Mehner T. 2005. Interactions between juvenile roach or perch and their invertebrate prey in littoral reed versus open water enclosures. Ecology of Freshwater Fish 14 (2): 150-160. DOI: 10.1111/j.1600-0633.2005.00086.x

Persson L., Hansson L.-A. 1999. Diet shift in fish following competitive release. Canadian Journal of Fisheries and Aquatic Sciences 56 (1): 70-78. DOI: 10.1139/f98-141

Peterka J., Matěna J. 2009. Differences in feeding selectivity and efficiency between young-of-the-year European perch (Perca fluviatilis) and roach (Rutilus rutilus) - field observations and laboratory experiments on the importance of prey movement apparency vs. evasiveness. Biologia 64 (4): 786-794. DOI: 10.2478/s11756-009-0133-4

Pivnička K. 1981. Ekologie ryb: odhady základních parametrů charakterizujících rybí populace. 1st edn. [Fish ecology: estimation of basic parameters characterizing fish populations.] SPN Praha, Czech Republic. [In Czech.]

Pivnička K. 1992. The Klíčava Reservoir, Czechoslovakia: A 30 year study of the fish community. Fisheries Research 14 (1): 1-20. DOI: 10.1016/0165-7836(92)90069-6

Ponton D., Gerdeaux D. 1988. Quelques aspects de l'alimentation de deux poissons planctonophages du lac Léman: le córegone (Coregonus schinzii palea Cuv. et Val.) et le gardon (Rutilus rutilus (L.)). Bulletin Français de la Pêche et de la Pisciculture 308: 11-23. DOI: 10.1051/kmae: 1988011

Prejs A. 1976. Fishes and their feeding habits. Pp. 155-171. In: Pieczyńska E. (ed.) Selected problems of lake littoral ecology. Wydawnictwo Uniwersytetu Warszawskiego, Warszawa, Poland.

Prejs A. 1984. Herbivory by temperate freshwater fishes and its consequences. Environmental Biology of Fishes 10 (4): 281-296. DOI: 10.1007/BF00001481 
Prejs A., Jackowska H. 1978. Lake macrophytes as the food of roach (Rutilus rutilus L.) and rudd (Scardinius erythropthalmus L.). Species composition and dominance relations in the lake and food. Ekologia Polska 26 (3): 429-438.

Prejs A., Martyniak A., Boroń S., Hliwa P., Koperski P. 1994. Food web manipulation in a small, eutrophic Lake Wirbel, Poland: effect of stocking with juvenile pike on planktivorous fish. Hydrobiologia 275-276 (1): 65-70. DOI: 10.1007/BF00026700

Přikryl, I. 2006. Metodika odběru a zpracování vzorků zooplanktonu stojatých vod. [Methodology for zooplankton sampling in still waters and sample processing.] VÚV TGM Prague, Czech Republic. [In Czech.]

Richeux C., Arias-Gonzalez J.E., Tourenq J.N. 1992. Etude du régime alimentaire des gardons (Rutilus rutilus (L.)) du lac de Pareloup (Massif Central, France). Annales de Limnologie 28 (3): 245-252. DOI: 10.1051/limn/1992021

Sokal R.R., Rohlf F.J. 1995. Biometry. 3rd edn. Freeman, New York, NY, USA.

Specziár A., Tölg L., Bíró P. 1997. Feeding strategy and growth of cyprinids in the littoral zone of Lake Balaton. Journal of Fish Biology 51 (6): 1109-1124. DOI: 10.1111/ j.1095-8649.1997.tb01130.x

Szczyglińska A. 1987. Diet composition and daily feeding patterns of Rutilus rutilus (L.), in Włocławek dam reservoir in 1982-1984. Acta Ichthyologica et Piscatoria 17 (2): 55-68.

Tarkowska-Kukuryk M. 2008. Influence of submerged vegetation on the diet of roach (Rutilus rutilus L.) in shallow
Polesie lakes. Teka Komisji Ochrony i Kształtowania Środowiska Przyrodniczego 5A: 145-152.

Tarvainen M., Sarvala J., Helminen H. 2002. The role of phosphorus release by roach [Rutilus rutilus (L.)] in the water quality changes of a biomanipulated lake. Freshwater Biology 47 (12): 2325-2336. DOI: 10.1046/j.1365-2427. 2002.00992.x

Vašek M., Kubečka J. 2004. In situ diel patterns of zooplankton consumption by subadult/adult roach Rutilus rutilus, bream Abramis brama, and bleak Alburnus alburnus. Folia Zoologica 53 (2): 203-214.

Vašek M., Kubečka J., Matěna J., Sed'a J. 2006. Distribution and diet of $0+$ fish within a canyon-shaped European reservoir in late summer. International Review of Hydrobiology 91 (2): 178-194. DOI: 10.1002/iroh.200510835

Volta P., Jepsen N. 2008. The recent invasion of Rutilus rutilus (L.) (Pisces: Cyprinidae) in a large South-Alpine lake: Laggo Maggiore. Journal of Limnology 67 (2): 163-170.

Walker J.L., Younos T., Zipper C.E. 2007. Nutrients in lakes and reservoirs - a literature review for use in nutrient criteria development. VWRRC Special Report SR34-2007. Virginia Polytechnic Institute and State University Blacksburg, VA, USA.

Received: 3 May 2013 Accepted: 30 December 2013 Published electronically: 31 March 2014 